\title{
Gunter Schubert (ed.), Routledge Handbook of Contemporary Taiwan,
} Abingdon, Oxon \& New York, Routledge, 2016, 570 pp.

\section{Saša Istenič}

\section{(2) OpenEdition}

\section{Journals}

Electronic version

URL: http://journals.openedition.org/chinaperspectives/7236

DOI: 10.4000/chinaperspectives.7236

ISSN: 1996-4617

\section{Publisher}

Centre d'étude français sur la Chine contemporaine

Printed version

Date of publication: 1 March 2017

Number of pages: 104

ISSN: 2070-3449

\section{Electronic reference}

Saša Istenič, " Gunter Schubert (ed.), Routledge Handbook of Contemporary Taiwan, », China Perspectives [Online], 2017/1 | 2017, Online since 01 March 2017, connection on 24 September 2020. URL : http:// journals.openedition.org/chinaperspectives/7236; DOI : https://doi.org/10.4000/chinaperspectives. 7236 


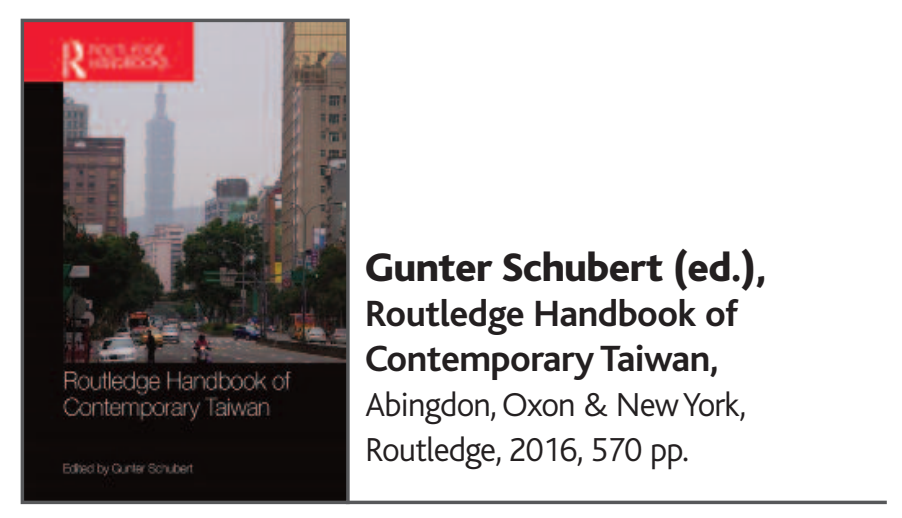

\section{SAŠA ISTENIČ}

ncreasingly overshadowed by China, whose long-term objective for Taiwan is well known, Taiwanese are striving hard to find a balance between safeguarding Taiwan's sovereignty and normalising cross-Strait relations. Accordingly, politics is always thick in the air, present in many aspects of daily life in Taiwan, and at the heart of both social and personal issues. Political issues are the toughest to deal with and will most likely remain unresolved in the near term. In view of that, it is more than appropriate to adopt politics as an underlying theme in the new Routledge Handbook of Contemporary Taiwan. An edited 570-page volume weighing over one kilogram, it is a highly impressive collection of academic articles that scrupulously detail the sensitivities Taiwan has struggled with in the past and present, and that it will most likely continue to struggle with in the foreseeable future.

The Handbook is organised into six parts. The first part reminds the reader about Taiwan's unique historical development, embracing not just a detailed overview of Taiwan's key politico-historical realities from the late Ming to the present but also exposing some fresh perspectives in interpreting historical facts and highlighting differing historical narratives and terminology. Retracing the liberalisation and democratisation processes as well as ongoing struggles with the authoritarian legacy, the first part wraps up with an insightful summary of Taiwan's independence movement, exposing both the uniqueness and paradox of Taiwan's de facto independence.

The second part focuses on Taiwan's domestic politics, alluding to some of the most significant issues that beset Taiwan's government today. In particular, the section reviews key trends of continuity and change in Taiwan's party politics, scrutinises the party system's ideological aspects, explores the development and influence of local factions, and provides a thorough scholarly overview of Taiwan's presidential, legislative, and local elections. It continues by investigating Taiwan's vibrant identity politics, thereby underlining the tension between social change and the political boundaries imposed by the transfer of Taiwan to China in 1945. It then brings forward the challenges of achieving transitional justice in post-war Taiwan and underscores the powerful role of Taiwan's media in the island's political processes.

The third part covers the issues related to Taiwan's political economy. The first chapter argues that the developmental state continues to impact Taiwan's post-war transformation and remains critical for its future economic, social, and political development. The next chapter provides some major observations of a new sub-field in the study of cross-Strait political relations, political economy, and migration - the Taishang studies, elaborating on a number of issues concerning Taiwan's mainland entrepreneurs. The final chapter contends that Taiwan's adjustments to the changing global economic situation are closely connected to its calculations on economic security and its "national grand strategy," and are accordingly inevitably affected by China.

A more comprehensive Part Four focuses on Taiwan's society and culture. Its nine chapters outline the development of civil society organisations, the progression of indigenous movements and their effects on Taiwanese society, the historical development of Taiwan's labour movement, the political significance of Taiwan's anti-nuclear movement and the fourth nuclear power plant controversy, Taiwan's resilient women's movement, the intriguing interaction between religion and politics in Taiwan, and the development and regime characteristics of Taiwan's social welfare, as well as providing a fresh overview of trends in modern Taiwan literature, and exploring the impact of democratisation on culture by applying the development of Taiwan cinema as a case study.

Part Five discusses the shifting cross-Strait relationship and policies, covering some of the most sensitive issues in the complex cross-Strait economic integration. It analyses the impact of China's rise and outlines the structure of Taiwan's economic dependence on China, as well as elucidating the political sensitivities surrounding cross-Strait marriages and immigration policies.

The final part discusses international relations and security. After a detailed overview of the changing course of Taiwan's foreign policy and ensuing implications to Taiwan's international space, the topic shifts to Taiwan's security relations with the United States, Taiwan's position and role in the contentious South China Sea, and Taiwan's relations with the European Union and Europe in general. The last two chapters bring in a concise review of Taiwan's security policy and Taiwan's public diplomacy.

All in all, the Handbook is very well-structured and coherent. Being a massive collection of 34 scholarly papers written by different authors, it has some minor limitations related to repetition and consistency in transliteration and referencing, but considering the remarkably broad spectrum of information it offers, such limitations are reasonable. Most crucially, the reading is compelling and never gets monotonous. Written by well-recognised experts and long-time Taiwan watchers, the volume is a real treasure trove as it provides a highly reliable source of Taiwan-focused topics and raises a number of important issues that are at the forefront of contemporary Taiwan. Furthermore, it renders a comprehensive, systematic, and welldocumented review of literature on Taiwan's most important historical, political, economic, social, and cultural developments. It is undoubtedly a publication that has been long awaited and deserves an immediate place on the shelves of academic libraries and of all those interested in the field of Taiwan studies. In short, anyone seeking insights into contemporary Taiwan should make sure to read it.

\section{Dr. Saša Istenič is Assistant Professor of Sinology at the} Department of Asian Studies of the University of Ljubljana and Director of the Taiwan Study Center in Slovenia (sasa@tajvan.si). 